INSECTS OF THE NORTHERN PAR'TS OF BRITISH AMERICA.

COMPILED BY THE REV. C. J. S. BETHUNE, M. A.

From Kirby's Fauna Boreali-Americana: Insecta.

(Continued from Page 132.)

3i 2. Coccinella quinque-signata Kirby.-Plate vii, fig. I. Length of body 3 lines. A single specimen taken in Lat. $65^{\circ}$.

Body oblong-hemispherical, very minutely and thickly punctured; underneath black and a little downy. Head black with an acute white spot in the forehead between the eyes; antennæ obscurely rufous, dusky at the base and tip; prothorax black, anterior angles and intermediate streak white; elytra tawny yellow with an abbreviated band common to both at the base, an oblique discoidal abbreviated band and apical dot, black; four distant lateral triangular white spots mark the breast.

$3^{\mathrm{T}} 3$. Coccinella Quinquenotata Kirby. - Length of body $3^{\mathrm{T} / 3}$ lines. A single specimen taken in Lat. $54^{\circ}$. Taken also by Dr. Bigsby in Canada.

[23r.] Very like the last, but shorter and more hemispherical. Two subtriangular transverse spots between the eyes, apex of the nose, dot at the sinus of the eyes, and anterior angles of the prothorax whitish-yellow; basal band of the elytra broadest at the suture, the two other black spots are of equal size and placed transversely, and each forms an abbreviated band, falling far short of the suture and the lateral margin, so as to be scarcely more than two transverse spots; scutellar angle of the elytra paler than the rest; the breast has no white spots. In other respects it is exactly like C.5-signata.

314. Coccinelta tricuspis Kirby. - Length of body $2 \frac{1}{4}$ lines. Several specimens taken in the journey from New York to Cumberlandhouse.

Body black, punctured. Head with two irregular transverse yellow spots between the eyes; antennæ pale rufous, black at the tip ; prothorax with the anterior angles and a slender portion of the anterior margin 
yellow, the black part forming a large three-lobed spot; the middle lobe being the longest and truncated, the lateral ones shorter and rounded; elytra tawny-rufous, paler and almost yellow at the base and sides, where there is a black band common to both elytra not reaching the lateral margin, which anteriorly has a double sinus so as to form three triangular lobes or points in the band; towards the apex of each elytrum is another irregular black band, which reaches neither the suture nor the margin.

3 5. Coccinella incarnata Kirby.-Plate vii, fig. 7. Length of body 2 lines, A single specimen taken in Lat. $65^{\circ}$.

[232.] Body black. Mouth and its organs and antennæ reddish; prothorax flesh-coloured with two large subquadrangular black spots, separated by a narrow flesh-coloured stripe, which occupy almost all the disk; elytra flesh-coloured, taken together with eleven roundish rather large black spots, three of which are common to both clytra, viz., 3, 4, 3, $\mathrm{r}$, the common spot at the apex is tranverse; legs black with the base of the thighs and tibiæ, tarsi, sides of the abdomen, and anus testaceous.

This species seems to come near $C$. borealis of Thunberg, but it differs in colour and the number and disposition of the spots.

\section{FAMILY PIMILIADE.}

3i6. Pimelia alternata Kirby.-Plate v, fig. 9. Length of body $6 \mathrm{I} / 2$ lines. A single specimen taken at Carlton-house, Lat. $53^{\circ}$, in April.

[233.] Body dull-black, oblong, naked. Head minutely punctured ; antennæ shorter than the prothorax; prothorax widest in the middle, subquadrangular with the sides rounded, minutely but not very thickly punctured, with some slight impressions in the disk; scutellum short, wide, rounded at the apex; elytra with six elevated granulated lines alternately more pronounced, besides the suture and marginal one separating the epipleura, which meet just above the apex ; epipleura granulated; posterior legs much longer than the four anterior.

Mr. Say says of his $P$. rotunda that it was the first of that genus found on the New Continent; that above described furnishes therefore a valuable addition to the American insect Fauna. Africa appears to be the metropolis of the genus, though several species have been found in Russian Tartary. 
[A species of Eleodes, synonymous with Say's Eleodes (Blaps) tricostata.]

\section{FAMILY TENEBRIONIDE.}

3I7. UpIS Cerambordes Linn. - Length of body $8-8 \mathrm{I} / 2$ lines. A pair taken in the month of April, in Lat. $65^{\circ}$. Taken also in Canada by Dr. Bigsby. [Abundant throughout Canada; taken by $\Lambda$ gassiz's Expedition on Lake Superior.]

Body dull-black, narrow, naked, minutely punctured. Head nearly round, depressed, porrected; eyes lateral, kidney-shaped; nose circumscribed by the segment of a circle; antennæe a little shorter than the prothorax, joints obconical, four last lentil-shaped; prothorax a little wider than the head, oblong with rounded sides; scutellum rounded at the apex; elytra taken together wider than the prothorax, a littie dilated beyond the middle, and then sloping to the apex, which is acute; very une qual with numerous irregular deep impressions and rugosities, variously separated by a number of elevated lines or obtuse ridges running confusedly in various directions; legs long; thighs incrassated; tibire and tarsi slender.

[234.] 318. Tenjebrio MoltTor Linn.-Length of body $7 \frac{1}{2}$ lines. Taken in Nova Scotia by Capt. Hall.

Body oblong-linear, minutely and numerously punctured, a little glossy, naked, above piceous, underneath rufo-piceous. Head uneven, nearly orbicular ; anteriorly rufo-piceous ; antennæ and palpi rufo-piceous ; prothorax transverse, sides rounded with a reflexed margin; posterior margin wavy, just above which, on each side, is a roundish impression; posterior angles acuminate; scutellum transverse, subacuminate; elytra scarcely wider than the prothorax, slightly furrowed, furrows punctured with the interstices transversely somewhat wrinkled, and most numerously and minutely punctured; shoulders short, compressed and incrassated; cubit curved.

[An introduced European species that has spread all over Canada and the Northern States, and has become a great pest to millers, flour dealers and house-keepers.]

Tenebrio Pennsyluanicus Knoch.-Length of body 8-9 lines. Several specimens taken in Lat. $54^{\circ}$; it was also sent me by Dr. Harris. 
[235.] Body long, rather widest towards the anus, black, minutely punctured, naked, not glossy. Head somewhat quadrangular, longer than in the preceding species, uneven; prothorax nearly square with a minute impression above the scutellum; posterior margin wavy; lateral very slender and a little rounded; scutellum subtriangular; elytra with nine rows, including the marginal one, of punctures, and an abbreviated one at the base next the suture; under a powerful lens the interstices are minutely but not thickly punctured; the shoulders are scarcely thicker than the thighs.

[Belongs to Nyctobates Guen.; very abundant throughout Canada.]

\section{ANNUAL MEETING OF THE ENTOMOLOGICAL SOCIETY OF ONTARIO.}

The third annual general meeting of the Society was held at the rooms, London, Ontario, on Thursday afternoon, Sept. $25^{\text {th, }} 1873$. The President, the Rev. C. J. S. Bethune, in the chair.

The minutes of the previous meeting were read and confirmed.

The Secretary-Treasurer then read the financial statement, showing a balance of $\$ 171.27$ on hand.

On motion this report was received and adopted.

The President then delivered his annual address, a copy of which will be found on another page.

Officers for the ensuing year were then elected, as follows :-

President, Rev. C. J. S. Bethune, M. A., Port Hope ; Vice-President, Mr. E. B. Reed, London ; Secretary-Treasurer, Mr. Joseph Williams, London. Council-Mr. Wm. Saunders, London; Mr. R. V. Rogers, Kingston; Rev. Canon Innes, London; Mr. Geo. J. Bowles, Montreal ; Mr. J. M. Denton, London. Auditors-Mr. C. Chapman, London ; Mr. I. H. Griffiths, London.

The Secretary read a letter from Mr. Caulfield, of Montreal, on behalf of the Entomologists resident there, requesting permission to form a Branch Society in that city. This was most cordially given, and the Secretary was instructed to convey to Mr. Caulfield the best wishes of the parent Society for the future success of the Montreal Branch. 